\title{
The Analysis of the Influence of Trump's Tax Reform on China's Unemployment Rate
}

\author{
Yumeng Lai* \\ Business school \\ East China University of Political Science and Law \\ Shanghai, China \\ sinoedie@foxmail.com
}

\begin{abstract}
With the passage of the final version of the "Trump tax reform" bill, the United States ushered in the largest tax reform bill during the past 30 years since the Reagan administration's tax reform. The tax reform bill will have a wide range of impact on the United States and the world. As one of the largest trading partners of the United States, China is bound to face a challenge. This article introduced the basic content of the "Trump tax reform" bill and pointed out its impact on China. At the same time, it uses the data from the Yangtze River Delta region as a sample of the study and the empirical analysis of the econometric model to find the impact of the tax reform on China's unemployment rate and put forward corresponding suggestions, and countermeasures.
\end{abstract}

Keywords-“Trump tax reform" bill; Unemployment rate; Econometric analysis

\section{INTRODUCTION}

On December 22 2017, the U.S. president Trump signed the "Tax Reduction and Employment Act" at the White House. And this act will come into effect since January 2018.

As the name implies, the bill mainly targets at the U.S. tax system, and intersects various industries and fields though changes in a series of basic tax policies such as personal income tax rate, individual tax exemption, corporate income tax rate, and one-time interest repatriation rate. The purpose of the implementation of the tax reform by the Trump administration is to induce a return flow of overseas capital and increase the competitiveness and vitality of US companies, which will improve the domestic capital investment environment, and increase the consuming power of the domestic market.

Obviously, in the modern era of economic globalization, this tax reform will bring various influences to China, and the unemployment rate will be an important aspect that cannot be ignored. The unemployment rate is closely related to the living standards of the people and affects the most important part of the family income. It has always been the focus of public discussion. The fluctuation of the unemployment rate will cause people's great concern, affecting the stability and development of society.

Therefore, China needs to stand firm in the influence of this tax reform, seize the opportunity, and implement effective countermeasures as soon as possible, to improve its economic resilience.

\section{MAIN CONtEnTS OF THE "TRUMP’s TAX REFORM" BILL}

Table I contains the main content of the bill.

\section{A. Lower Personal Income Tax}

From Table I, we can see that in terms of individual taxes, the changes to the "Trump tax reform" bill mainly include:(1) Reducing the original personal income tax rate to seven levels: $10 \%, 15 \%, 25 \%, 28 \%, 33 \%, 35 \%$ and $39.6 \%$ were respectively reduced to $70 \%$ of the $10 \%, 12 \%, 22 \%, 24 \%$, $32 \%, 35 \%$ and $37 \%$. (2) Increase the tax exemption. Individual taxpayers and co-filers have almost doubled their tax exemption.(3) Raise the inheritance tax threshold. Inheritance tax threshold was increased from $\$ 5.43$ million to $\$ 11$ million.

(4) Cancel the net investment income tax.

\section{B. Lower Corporate Income Tax}

Table II shows the current comparison of corporate income tax rates in some countries.

From Table II, we can see that the figure of corporate income tax rate before the US tax reform is relatively high in major countries in the world, and the Trump Tax Reform Act reduces the rate from $35 \%$ to $21 \%$. This will greatly reduce the operating cost and tax burden of enterprises and increase the attractiveness of the United States to foreign capital.

\section{Attracting the Return of the United States Overseas Capital}

Prior to the tax reform, when U.S. companies remitted overseas profits to America they should pay a $35 \%$ tax, and the tax reform bill changed it to $14 \%$. This means that the amount of taxes required by U.S. companies to repatriate overseas profits to the country is greatly reduced. This will greatly encourage the reinvestment of capital from overseas companies back to the United States. 
TABLE I. COMPARISON BETWEEN THE TAX REFORM AND THE ORIGINAL TAX SYSTEM ${ }^{(1)}$

\begin{tabular}{|c|c|c|}
\hline $\begin{array}{c}\text { Tax Reform } \\
\text { Project }\end{array}$ & $\begin{array}{c}\text { Content of Tax } \\
\text { Reform }\end{array}$ & $\begin{array}{l}\text { Original Tax } \\
\text { Rules }\end{array}$ \\
\hline $\begin{array}{l}\text { Personal Income } \\
\text { Tax }\end{array}$ & $\begin{array}{l}\text { Seven Grade: } 10 \% \text { 、 } \\
12 \% 、 22 \% 、 24 \% 、 \\
32 \% 、 35 \% 、 37 \%\end{array}$ & 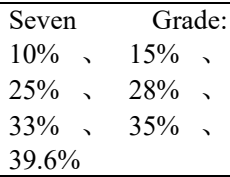 \\
\hline $\begin{array}{l}\text { Corporate Income } \\
\text { Tax }\end{array}$ & $21 \%$ & $35 \%$ \\
\hline $\begin{array}{l}\text { Personal Income } \\
\text { Tax Exemption }\end{array}$ & $\begin{array}{l}\text { Individual } \\
\text { Filer }: \$ 12,000 \\
\text { Co-filers: } \$ 24,000\end{array}$ & $\begin{array}{l}\text { Individual } \\
\text { Filer :\$6,350 } \\
\text { Co-filers: } \$ 12,700\end{array}$ \\
\hline Inheritance Tax & $\begin{array}{l}\text { Threshold : } \$ 11 \\
\text { million }\end{array}$ & $\begin{array}{l}\text { Tax } \\
\text { Exemption: } \$ 5.43 \\
\text { million, } 18 \%-48 \% \\
\text { for the } \\
\text { excess }\end{array}$ \\
\hline $\begin{array}{l}\text { Net Investment } \\
\text { Income Tax }\end{array}$ & $\begin{array}{l}\text { Cancellation or } \\
\text { phasing out within } 5 \\
\text { years }\end{array}$ & $\begin{array}{l}\text { Individuals earning } \\
\text { over } \$ 200,000 \text { and } \\
\text { annual household } \\
\text { income exceeding } \\
\$ 250,000 \text { must pay } \\
3.8 \% \text {. }\end{array}$ \\
\hline $\begin{array}{l}\text { Repatriation Tax } \\
\text { Rate of One-time } \\
\text { Profit }\end{array}$ & $14 \%$ & $35 \%$ \\
\hline Global Tax System & Be exempt from tax & Must be taxed \\
\hline $\begin{array}{l}\text { Child Tax } \\
\text { Benefits }\end{array}$ & $\begin{array}{l}\text { tax credit increased to } \\
\$ 2,000 \text { and the full } \\
\text { refund amount can be } \\
\text { increased to } \$ 1,400\end{array}$ & Tax credit $\$ 1,000$ \\
\hline
\end{tabular}

TABLE II. COMPARISON OF CORPORATE INCOME TAX RATES IN SOME COUNTRIES $^{(2)}$

\begin{tabular}{|c|c|c|l|l|l|l|l|}
\hline $\begin{array}{c}\text { COU } \\
\text { NTRI } \\
\text { ES }\end{array}$ & $\begin{array}{c}\text { AM } \\
\text { ERI } \\
\text { CA }\end{array}$ & $\begin{array}{c}\text { CH } \\
\text { IN } \\
\text { A }\end{array}$ & $\begin{array}{c}\text { JAP } \\
\text { AN }\end{array}$ & $\begin{array}{c}\text { AUST } \\
\text { RALI } \\
\text { A }\end{array}$ & $\begin{array}{c}\text { FR } \\
\text { AN } \\
\text { CE }\end{array}$ & $\begin{array}{c}\text { GER } \\
\text { MAN } \\
\text { Y }\end{array}$ & $\begin{array}{c}\text { IREL } \\
\text { AND }\end{array}$ \\
\hline $\begin{array}{l}\text { TAX } \\
\text { RATE } \\
(\%)\end{array}$ & 35 & 26 & 23 & 30 & 33 & 17 & 13 \\
\hline
\end{tabular}

\section{RELATED LitERATURE}

There are many opinions in the academic community about the impact of the Trump's Tax Reform on China. The author has summarized and consolidated these views as follows.

\section{A. Positive Influences}

D.S. Li believes that by reducing personal income tax rate, US residents' consuming power will increase. This will bring the increase of the export of Chinese companies and promote the development of related companies, which will have a positive impact on Chinese export enterprises [1].

The origin of the "Trump Tax Reform" Act and original tax information is the White House website:

https://www.whitehouse.gov/.

Data source: D.S. Li, “An analysis of the influence of Trump tax deduction on China's tax reform, "Journal of Changchun Normal University, vol. 37, pp. 48-52, 2018.

\section{B. Negative Impacts}

1) Attracting more Chinese capital to the United States and reducing Chinese domestic investment: Y.X. Wang mentioned that China's direct investment in the United States from 2014 to 2016 was $\$ 7.6$ billion, $\$ 8.03$ billion, and $\$ 16.98$ billion respectively, an increase of $96.1 \%, 5.7 \%$, and $111.5 \%$ year-on-year [2]. It can be seen from this that the United States has become more and more attractive to Chinese capital. H.J. Li and Y.Z. Zhang believe that with the implementation of the tax reform policy by Trump, the U.S. enterprise operating environment will become more advantageous, and this measure will attract more Chinese companies to invest in the United States in the future [3]. More and more Chinese capital flows to the United States means that the capital remaining in China will be reduced accordingly. There will be a rise in unemployment rate of China.

2) Promoting the return of U.S. capital to its own country and reduce China's attraction to foreign investment: Trump's Tax Reform will lower the corporate income tax rate and optimize the US business environment. Z Xu deem that this will not only make more Chinese companies willing to invest in the United States, but also enable US companies in China to re-enter capital back to the United States and enjoy the benefits of low tax rates. [4]. According to $\mathrm{T} \mathrm{Lu}$, as the onetime profit repatriation tax rate is drastically reduced, the repatriation costs of U.S. overseas capital will be reduced, which is expected to guide the return of U.S. companies' overseas retained profits. [5]. X.H. Zhao also believes that in the short term, Trump's repatriation of overseas profits policy will prompt some American companies to return overseas profits to their home countries [6]. C.M. Li mentioned in his article that the Trump tax reform policy will bring about certain negative impact on China's introduction of foreign funds [7].

3) The competitiveness of Chinese import and export enterprises will decline: By reducing the tax rate, Trump's Tax Reform will directly reduce the tax burden of enterprises, and enable companies to use the saved taxes to expand production and conduct research. Y Dai believes that the tax reform will greatly enhance the competitiveness of US companies. Correspondingly, the competitiveness of Chinese import and export companies will be weakened, making them difficult to resist the ferocious momentum of American companies in the market [8]. The decline in the competitiveness of Chinese import and export companies will affect the entire industry gradually, and ultimately will have a negative effect on China's economic development.

4) Pressure of RMB depreciation increases, accelerating capital outflow from China: Trump's Tax Reform will make the U.S. more attractive for foreign investment. This will lead to a stronger U.S. dollar and downward pressure on the exchange rate of the RMB. Although a certain degree of devaluation of the RMB is conducive to the export of Chinese corporate products, if the RMB exchange rate continues to fall, 
it will worsen the market's expectation of devaluation and accelerate the speed of capital outflows, ultimately affecting China's economic development. Y.S. Jiang believes that this tax reform will lead to a stronger US dollar and an increase in the pressure of RMB devaluation, which is not conducive to the stable development of China's economy [9].

5) Triggering a global tax cut that has multiple effects on China: In order to deal with the impact of Trump's Tax Reform, various countries around the world will formulate corresponding measures. M.J. Wang thinks that European countries represented by Britain, France, and Germany will follow the pace of tax cuts, which will cause a global wave of tax cuts, and have a cumulative impact on China [10]. L.X. Huang believes that the US tax reform will intensify the bottom-up competition between corporate income tax rates in various countries [11].

\section{THE INFLUENCE OF TRUMP'S TAX REFORM ON CHINA'S UNEMPLOYMENT RATE}

The unemployment rate is a very important economic indicator. It is related to the people's most basic source of income. Meanwhile it is also closely related to economic development. Although Trump's Tax Reform occurs in the United States on the other side of the ocean, it will also affect China's unemployment rate. This paper argues that Trump's Tax Reform will first produce the positive and negative effects which are listed above on China, and will then directly affect China's unemployment rate through these influences.

The specific influences include:

\section{A. The Positive Influences on the Unemployment Rate}

On the positive side, Trump's Tax Reform will improve the consumption capacity of the United States residents and promote the development of Chinese export enterprises. The accelerated development of Chinese export enterprises will stimulate the development of China's other industries and promote its economic growth. Therefore, as the economic growth and the corporate efficiency increasing, the jobs will increase. So the unemployment rate will be reduced.

\section{B. The Negative Influences on the Unemployment Rate}

1) More Chinese capital will flow to the USA: Trump's Tax Reform will lead to more Chinese capital flows to the United States. Therefore it will transfer large amounts of capital originally invested in Chinese market to the United States. Chinese companies will reduce their domestic investment, slowing the pace of plant production and research in China. Thus this will affect the development of companies' upstream and downstream enterprises, leading to fluctuations in the entire industry and will ultimately make a far-reaching impact on China's economic development. In this unfavorable situation, in order to minimize losses, many companies will reduce staff wages and make layoffs. This will lead to the increase of the unemployment rate. Meanwhile, with lower wages and rising unemployment rate, people's consuming capacity will be hit hard, which will in turn affect corporate income. So the companies will reduce staff wages and make layoffs again, thus this will plunge into a vicious cycle of rising unemployment rate.

2) U.S. capital in China flows back, China's attractiveness to foreign investment declines: We have already known that the other effect of Trump's Tax Reform on China is to bring the US capital back to the US. When China's attractiveness to foreign investment declines, the amount of foreign capital and capital inflows will decrease correspondingly. That will have a big impact on companies and factories which were set up by foreign capital. This situation will cause unemployment rate to rise. The decrease in foreign capital inflows indicates that foreign capital inflows to China are no longer as many as before, which will exacerbate the impact of the aforementioned increase in foreign capital outflows and adversely affect the unemployment rate.

3) The decrease of the competitive power of China's import and export enterprises: When American companies become more competitive, they will seize the share of Chinese companies in the international market and blow up the momentum of Chinese enterprises' development. China's import and export enterprises will suffer from product income reduction and other huge impacts. So their own competitive power is bound to decline. Therefore they will reduce production and investment, affecting other domestic enterprises through the ripple effect and ultimately bring negative effects to the whole industry. When the whole industry's companies reduce staff wages and make layoffs, the whole society will be plunged into the death cycle of rising unemployment rate, seriously hampering the operation and development of China's economy.

4) $R M B$ depreciation pressure increases: From the foregoing, Trump's Tax Reform will enable the dollar but weaken the RMB, and thus accelerate the outflow of foreign capital in China. The accelerated outflow of foreign capital in China will lead to the increase of China's unemployment rate and hinder China's economic development.

5) The global wave of tax cuts: Trump's Tax Reform will set off a wave of global tax cuts, leading countries to introduce corresponding tax cuts. So, China will not only face the impact of Trump's Tax Reform, but will also face other countries' impacts.

Although Trump's Tax Reform both has positive and negative impacts on China's employment rate, its negative impacts will greatly outweigh the positive impacts.

Therefore, the paper argues that this tax reform will raise China's unemployment rate, affecting the stability of Chinese society, and hinder the steady development of China's economy. 


\section{VERIFICATION AND ANALYSIS OF ECONOMETRIC MODEL}

\section{A. Verification Purpose}

From the above analysis, we can see that Trump's Tax Reform will bring many complex impacts on China. These impacts will be specific to the investment of Chinese enterprises, foreign investment in China, Chinese import and export, average wages and GDP. This article argues that Trump's Tax Reform will eventually bring negative changes to China's unemployment rate through the link between these factors and the unemployment rate. The purpose of this econometric analysis is to verify that there is a real correlation between these factors and the unemployment rate, and then confirm that Trump's Tax Reform has a negative impact on China's unemployment rate.

\section{B. Sample Screening and Data Sources}

In order to ensure the convenience of data collection and the accuracy of inspection, this operation uses the Yangtze River delta area as an example and the selected samples are the economic data of Jiangsu, Zhejiang province and Shanghai city. Then this operation is based on the Jiangsu, Zhejiang and Shanghai three places and 1997-2016 years of the time series to build panel data. The data of Shanghai area are derived from Wind database, Jiangsu province's data are from Statistic Yearbook of Jiangsu Provincial Bureau of Statistics and Zhejiang province's data are from Statistic Yearbook of Zhejiang Provincial Bureau of Statistics. In order to make the result more academic rigorous and for data integrality, this paper has eliminated the year which misses data. After the above screening, this article obtained 38 samples. All the data in this paper are sorted by Excel, and the StataSE12.0 software is used to calculate regression analysis. The whole data are annual data.

\section{Model Construction and Variable Interpretation}

The econometric model is:

$$
R O U=\mathrm{a} 0+\mathrm{a} 1 G D P+\mathrm{a} 2 A W+\mathrm{a} 3 O I+\mathrm{a} 4 F I+\mathrm{a} 5 T E I+\eta
$$

Equation (1)'s variable interpretation:

ROU: The unemployment rate of three region in Jiangsu, Zhejiang province and Shanghai city ( \% ).

GDP: The respective gross domestic product (100 million yuan).

AW: The respective average wage (yuan).

OI: The respective local enterprises' foreign investment (10 thousand USD).

FI: The investment of foreign enterprises in Jiangsu, Zhejiang province and Shanghai city (10 thousand USD).

TEI: Jiangsu, Zhejiang province and Shanghai city's total trade volume (10 thousand USD).

$\eta$ : Random perturbation term.

D. Empirical Analysis
1) Descriptive statistics: Table III shows the data descriptive statistics.

TABLE III. DATA DESCRIPTION

\begin{tabular}{|l|l|l|l|l|l|}
\hline $\begin{array}{l}\text { Varia } \\
\text { ble }\end{array}$ & $\begin{array}{l}\text { Mean } \\
\text { value }\end{array}$ & $\begin{array}{l}\text { Maximu } \\
\mathbf{m} \text { Value }\end{array}$ & $\begin{array}{l}\text { Minimu } \\
\mathbf{m} \text { value }\end{array}$ & Median & $\begin{array}{l}\text { Standard } \\
\text { deviation }\end{array}$ \\
\hline ROU & $\begin{array}{l}3.5084 \\
21\end{array}$ & 4.5 & 2.87 & 3.285 & 0.505449 \\
\hline GDP & $\begin{array}{l}26351 . \\
82\end{array}$ & 76086.17 & 4686.71 & 19701.82 & 19701.82 \\
\hline AW & $\begin{array}{l}34074 . \\
93\end{array}$ & 72684 & 8386 & 31158.5 & 16634.66 \\
\hline OI & $\begin{array}{l}87106 \\
6.6\end{array}$ & 2808140 & 5240 & 503067.5 & 881430 \\
\hline FI & $\begin{array}{l}80071 \\
72\end{array}$ & $3.99 \mathrm{e}+07$ & 131802 & 1076988 & $1.25 \mathrm{e}+07$ \\
\hline TEI & $\begin{array}{l}9.87 \mathrm{e}+ \\
07\end{array}$ & $3.55 \mathrm{e}+07$ & $1.42 \mathrm{e}+07$ & $4.88 \mathrm{e}+07$ & $1.08 \mathrm{e}+07$ \\
\hline
\end{tabular}

2) Correlation analysis: Table IV is the dependency condition of the model variable.

TABLE IV. DEPENDENCY CONDITION

\begin{tabular}{|c|c|c|c|c|c|c|}
\hline Variable & ROU & GDP & AW & OI & FI & $\begin{array}{l}\mathbf{T} \\
\mathbf{E}\end{array}$ \\
\hline ROU & 1 & & & & & \\
\hline GDP & $\begin{array}{l}- \\
0.6554\end{array}$ & 1 & & & & \\
\hline AW & $\begin{array}{l}- \\
0.2904\end{array}$ & $\begin{array}{l}0.876^{*} \\
* *\end{array}$ & 1 & & & \\
\hline OI & $\begin{array}{l} \\
0.4818\end{array}$ & $\begin{array}{l}0.2906 \\
*\end{array}$ & 0.1905 & 1 & & \\
\hline FI & $\begin{array}{l}- \\
0.469 *\end{array}$ & $\begin{array}{l}0.8612 \\
*\end{array}$ & $\begin{array}{l}0.6838 \\
* * *\end{array}$ & -0.1503 & 1 & \\
\hline TEI & $\begin{array}{l}- \\
0.4688\end{array}$ & 0.2471 & 0.206 & $\begin{array}{l}0.9092 * * \\
*\end{array}$ & $\begin{array}{l} \\
0.24\end{array}$ & 1 \\
\hline
\end{tabular}

3) Regression analysis: Table $\mathrm{V}$ shows the regression results which are obtained by the software.

TABLE V. REGRESSION RESULT

\begin{tabular}{|l|l|l|}
\hline \multicolumn{1}{|c|}{ Variable name } & \multicolumn{1}{c|}{ Coefficient } & \multicolumn{1}{c|}{ significance } \\
\hline Constant & $3.41711^{* * *}$ & 0.000 \\
\hline GDP & $-0.001048 * * *$ & 0.001 \\
\hline AW & $-0.000056^{* * *}$ & 0.000 \\
\hline OI & $2.07 \mathrm{e}-07 *$ & 0.057 \\
\hline FI & $-7.77 \mathrm{e}-08^{* *}$ & 0.035 \\
\hline TEI & $-1.46 \mathrm{e}-09$ & 0.48 \\
\hline $\mathrm{R}^{2}$ & 0.8152 & \\
\hline F value & $33.64 * * *$ & 0.0000 \\
\hline
\end{tabular}

4) Result analysis: From the results of regression analysis, we can know that the model $\mathrm{R}^{2}$ value is 0.8152 . It means the fitting degree is relatively high and the relation between the explanatory variable and the interpreted variable can be accurately described. From Table V we can see that GDP, AW, FI and TEI are negatively correlated with the unemployment rate, that means the unemployment rate will rise when the value of these variables reduce. Among them, GDP and average wage have the most significant impact on 
the unemployment rate, indicating that the main factors affecting the unemployment rate are GDP and average wage. The impact of TEI on the unemployment rate is relatively small and negligible. On the other hand, the local enterprises' foreign investment is positively correlated with the unemployment rate, that means the unemployment rate increases with the increase of the amount of OI.

From the foregoing analysis, it can be seen that Trump's Tax Reform will reduce GDP, AW, FI and TEI and improve the local enterprises' foreign investment. From the results of econometric analysis, the reduction of four kinds of variables such as GDP will raise the unemployment rate, and the increase of the local enterprises' foreign investment will also raise the unemployment rate. Therefore, Trump's Tax Reform will eventually increase the unemployment rate in Jiangsu, Zhejiang province and Shanghai city, affecting the local economic development seriously. Similarly, Trump's Tax Reform will affect China as much as Jiangsu, Zhejiang province and Shanghai city, raising China's unemployment rate. Therefore, through the econometric analysis, the view of this article has been validated.

\section{CHINA'S RESPONSE MEASURES}

For Trump's Tax Reform's impacts on China, our country should be fully prepared to face and seize the opportunity. The recommendations presented in this article are as follows:

\section{A. Strengthen China's Tax System Reform}

In recent years, with the implementation of a series of tax cuts and tax reduction policies, the Chinese government has achieved relatively good results, corporate tax pressure has been alleviated, the tax system has become more scientific and reasonable, and the market economy is more vigorous. However, there is still much room for improvement in our tax system. The comparison of the total tax rate of the major countries is shown in Table $\mathrm{VI}^{1}$ :

TABLE VI. THE TOTAL TAX RATE OF EACH COUNTRY

\begin{tabular}{|c|c|c|c|c|c|}
\hline Countries & $\begin{array}{l}2013 \\
\text { year }\end{array}$ & $\begin{array}{l}2014 \\
\text { year }\end{array}$ & $\begin{array}{l}2015 \\
\text { year }\end{array}$ & $\begin{array}{l}2016 \\
\text { year }\end{array}$ & $\begin{array}{l}2017 \\
\text { year }\end{array}$ \\
\hline China & 68.80 & 68.60 & 67.90 & 68.20 & 67.30 \\
\hline France & 69.30 & 70.80 & 61.90 & 64.00 & 62.20 \\
\hline Germany & 49.10 & 48.80 & 48.80 & 48.90 & 48.90 \\
\hline Japan & 48.80 & 50.40 & 50.40 & 48.90 & 47.40 \\
\hline $\begin{array}{l}\text { United } \\
\text { States }\end{array}$ & 43.80 & 43.80 & 43.90 & 44.00 & 43.80 \\
\hline Singapore & 18.40 & 18.00 & 18.00 & 19.10 & 20.30 \\
\hline Average & 42.06 & 40.73 & 40.58 & 40.44 & 40.46 \\
\hline
\end{tabular}

By the Table VI, it can be seen that China's total tax rate is the highest in these countries. Over high tax rate will seriously discourage enterprise's production enthusiasm. At the same time, the United States-led new global wave of tax cuts will exacerbate this negative impact. Therefore, China should continue to deepen the tax reform, speed up the pace of tax

3 Data source: World Bank.[12] simplification, promote economic development and reduce the adverse impacts of Trump's Tax Reform.

\section{B. Optimize The Domestic Enterprises Operating Environment}

In order to avoid the occurrence of capital outflow, China should implement the policy of corporate friendliness such as fiscal and tax deduction, improve the efficiency of government affairs, perfect the basic supporting facilities and make efforts to establish a perfect legal system. At the same time, China also needs to ensure good market standard operation, further optimize the business environment of domestic enterprises, attract foreign capital inflow and promote economic development.

\section{Increase Supply Side Reform and Promote the Development of Real Economy}

China should further supply side reform and increase the number of consumer groups, so the enterprise will be willing to stay at home and have the power to increase production. Staying at home will increase domestic jobs, reduce the unemployment rate and promote economic development. At the same time, China also needs to revitalize the real economy to support the development of various industries, and improve enterprise innovation and research capabilities. Only owing the ability to continuously innovate and progress, can we truly form the never fail motor of economic growth.

\section{CONCLUSION}

This paper argues that Trump's Tax Reform will have a negative impact on China's employment situation, which will raise unemployment rate and hinder Chinese economic development.

Therefore, in this tax relief wave China should stand firm, be calm, see clear the nature of the problem, and use a variety of measures to occupy the active position. Also, China should optimize its own problems, enhance the ability to resist pressure, and be self-confident to face the challenges through this game.

\section{REFERENCES}

[1] D.S. Li, "An analysis of the influence of Trump tax deduction on China's tax reform," Journal of Changchun Normal University, vol. 37, pp. 48-52, 2018.

[2] Y.X. Wang, "Trump Tax reform : connotation, influence and coping," International Finance, pp. 47-53, 2018.

[3] H.J. Li and Y.Z. Zhang, "The influence of Trump's tax reform policy and China's strategy choice," Asia-pacific Economic Review, pp. 5$11+145,2018$.

[4] Z. Xu and J.Y. Wang, "Trump Tax reform: Capital Backflow, tax reduction competition and China's response," Caizheng Jiandu, pp. 8690, 2017.

[5] T Lu and S.Y. Chang, "Can Trump's tax change be fulfilled," World Affairs, pp. 38-39+42, 2017.

[6] X.H. Zhao, "Influence Analysis of Donald Trump's Tax Reform," Petroleum \& Petrochemical Today, vol. 26, pp. 8-14, 2018.

[7] C.M. Li and Y.J. Hu, "An Analysis of Donald Trump's Proposed Tax Reform and Its Impacts on China,” Taxation Research, pp. 42-46, 2017. 
[8] Y. Dai, "The Trump Tax Reform and Its International Impact," Journal of Central University of Finance \& Economics, pp. 3-12, 2017.

[9] Y.S. Jiang, "Thoughts on Trump Tax reform plan and China's coping strategies," International Taxation In China, pp. 32-37, 2017.
[10] M.J. Wang, G Gao, and Z.Y. Li, "How should China deal with Trump tax reform," Shangye Jingji, pp. 21-22, 2017.

[11] L.X. Huang, "An Overall Analysis of the Tax Cuts and Jobs Act," Taxation Research, pp. 18-24, 2018.

[12] Wrorld Bank Open Data, https://data.worldbank.org.cn/. 